\title{
STUDI POTENSI PEMISAHAN PELABUHAN BARANG DI PADANG BAI
}

\author{
Dewa Gde Mahatma Pandhit., Ir. Murdjito, M.Sc.Eng. dan Christino Boyke S.P., S.T., M.T. \\ Bidang Studi Transportasi Laut, Jurusan Teknik Perkapalan, FTK, Institut Teknologi Sepuluh Nopember (ITS) \\ Jl. Arief Rahman Hakim, Surabaya 60111 Indonesia \\ e-mail: dewapandit@gmail.com
}

\begin{abstract}
Abstrak-Pelabuhan penyebrangan Padang Bai merupakan pelabuhan yang melayani pengangkutan truk dan kendaraan pribadi dari Bali menuju ke NTB maupun NTT. Dari tahun ke tahun arus muatan di pelabuhan Padang Bai cenderung mengalami peningkatan, pada tahun 2013 untuk arus muatan truk di Padang Bai 95.537 unit meningkat menjadi 105.525 unit di tahun 2014, untuk sepeda motor dari 231.620 di tahun 2013 dan meningkat menjadi 256.460 menurut data ASDP pelabuhan Padang Bai 2015, akan tetapi luas lahan di Padang Bai terbatas. Dengan menggunakan metode regresi linear didapat persamaan untuk muatan truk dengan variable bebas PDB NTB y = -0.453 + 9.47x, untuk peramalan kendaraan pribadi dengan variable bebas tenagakerja Bali y $=0.24+2.17 x$, peramalan arus muatan untuk menganilsis kapasitas pelabuhan kedepannya. Dalam penilaian potensi digunakan metode Multi Criteria Decision Making (MCDM) untuk melakukan pengambilan keputusan. Kriteria yang digunakan adalah biaya operasional truk, Jarak antar pelabuhan, kebisingan, emisi udara, kerugian akibat antrian dan biaya pelabuhan. Penilaian terhadap alternatif didasarkan atas nilai masing-masing kriteria yang diperoleh dari perhitungan yang dilakukan. Alternatif lokasi yang terpilih adalah alternatif dengan nilai tertinggi. Dari hasil analisis beberapa kriteria, lokasi Amed memiliki nilai sebesar 0.83 sedangkan Padang Bai memiliki nilai 0.52 , sehingga pelabuhan penyeberangan truk lebih baik di Amed.
\end{abstract}

Kata kunci - Pelabuhan penyeberang, Regresi linear, Analisis Fasilitas Pelabuhan, MCDM

\section{PENDAHULUAN}

Pelabuhan Padang Bai merupakan pelabuhan yang melayani penyebrangan kapal dari Bali menuju ke Lombok, dan begitu juga melayani kapal yang dari Lombok menuju ke Bali. Arus muatan di pelabuhan Padang Bai cenderung mengalami peningkatan, pada tahun 2013 untuk arus muatan truk di Padang Bai 95.537 unit dan meningkat menjadi 105.525 unit di tahun 2014, sedangkan untuk arus muatan mobil pribadi pada tahun 2013 sebanyak 227.567 unit dan pada tahun 2014 menurun menjadi 220.299 unit, untuk sepeda motor dari 231.620 di tahun 2013 dan meningkat menjadi 256.460 menurut data ASDP pelabuhan Padang Bai 2015 [1]. Sehingga membutuhkan pengembangan pelabuhan untuk dapat melayani peningkatan arus muatan tersebut. Untuk melakukan pengembangan pelabuhan tersebut pelabuhan Padang Bai memiliki luasan lahan dan fasilitas yang terbatas, disamping itu pelabuhan Padang Bai dekat dengan lokasi wisata candi dasa sehingga jalur truck untuk pengangkut barang dinilai mengganggu aktifitas wisata.. Pemerintah Provinsi Bali berencana memindahkan pelabuhan barang dari Padang Bai, dan memfokuskan pelabuhan Padang Bai sebagai pelabuhan penumpang dan wisata.

Studi potensi merupakan kegiatan awal sebagai kajian umum dan penjajakan awal untuk pengumpulan atau mendapatkan data dan informasi tentang kemungkinan suatu daerah yang dapat dikembangkan dan dimanfaatkan. Berdasarkan hasil studi potensi ini menjadi masukan untuk pengambil keputusan untuk dilanjutkan atau tidak rencana tersebut dan bila ternyata memilik banyak potensi yang layak dapat membantu memilih suatu prioritas. Pembangunan pelabuhan memakan biaya yang sangat besar, oleh karena itu diperlukan suatu perhitungan, pertimbangan dan perencanaan yang masak untuk memutuskan pembangunan pelabuhan. Keputusan pembangunan pelabuhan biasannya didasari pada beberapa pertimbangan, anatar alain: ekonomi, politik dan bisnis. Pada pelabuhan khusus misalnya, produksi dari suatu perusahaan biasannya sudah diketahui sehingga, pelabuhan dapat direncanakan untuk memenuhi kebutuhan tersebut [2].

\section{URAIAN PENELITIAN}

\section{A. Identifikasi Masalah}

Setelah menentukan permasalahan yang muncul yaitu studi potensi pemisahan pelabuhan barang, dalam tahap ini diuraikan beberapa proses identifikasi terkait permasalahan dalam penelitian ini yaitu pengambilan keputusan pelabuhan barang di Padang Bai. Adapun beberapa identifikasi sebagai berikut:

a. Identifikasi Arus Muatan

Identifikasi arus muatan bertujuan untuk mengetahui proyeksi arus muatan di pelabuhan Padang Bai kedepannya.

b. Identifikasi Kapasitas Pelabuhan Padang Bai Identifikasi kapasitas pelabuhan untuk mengetahui kapasitas dari pelabuhan Padang Bai dalam melayani peningkatan arus muatan.

c. Identifikasi kriteria pengambilan keputusan

Pada tahap identifikasi kriteria pengambilan keputsan bertujuan untuk mengidentifikasi kriteria yang akan digunakan untuk pengambilan keputusan.

\section{B. Tahap Analisis}

Pada tahap analisis ini dilakukan perhitungan proyeksi arus muatan di pelabuhan Padang Bai di tahun-tahun kedepannya, kemudian menganalisa kapasitas pelabuhan Padang Bai hingga tahun berapa dapat melayani pertumbuhan arus muatan.

Setelah mengenalisa proyeksi arus muatan dan menganalisa kapasitas pelabuhan, maka akan dianalisa dampak dari jika pelabuhan penyeberangan truk tetap di 
Padang Bai, dan jika pelabuhan penyeberang truk dipindah di Amed. Dan terakhir melakukan pengambilan keputusan berdasarkan kriteria yang telah ditentukan dengan menggunakan metode $M C D M$.

\section{GAMBARAN UMUM}

\section{A. Lokasi pelabuhan Padang Bai}

Pelabuhan Padang Bai merupakan pelabuhan penyeberangan dari Bali menuju ke Lombok. Didaerah belakang pelabuhan Padang Bai terdapat berbagai tempat wisata, seperti pantai blue lagoon, dimana untuk menuju daerah wisata blue lagoon melalui jalan yang sama dengan jalan menuju pelabuhan Padang Bai.

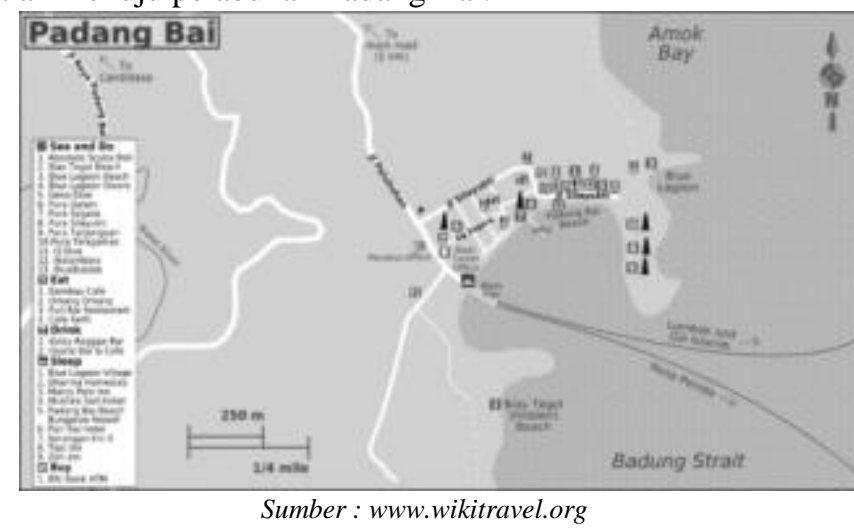

Gambar 1 Tempat wisata di daerah Padang Bai

Gambar 1 merupakan gambar dari daerah wisata yang berada di Padang Bai.

\section{B. Arus Muatan di Pelabuhan Padang Bai}

Arus muatan di pelabuhan Padang Bai di bagi menjadi 2, yaitu :

a. Kendaraan Barang (Truk)

Arus truk di pelabuhan Padang Bai mengalami peningkatan dari tahun sebelumnya. Sebagian besar kendaraan yang menyeberang di pelabuhan Padang Bai adalah truk. Truk yang menyeberang di pelabuhan Padang Bai sebagian besar merupakan truk yang membawa barang dari jawa timur.

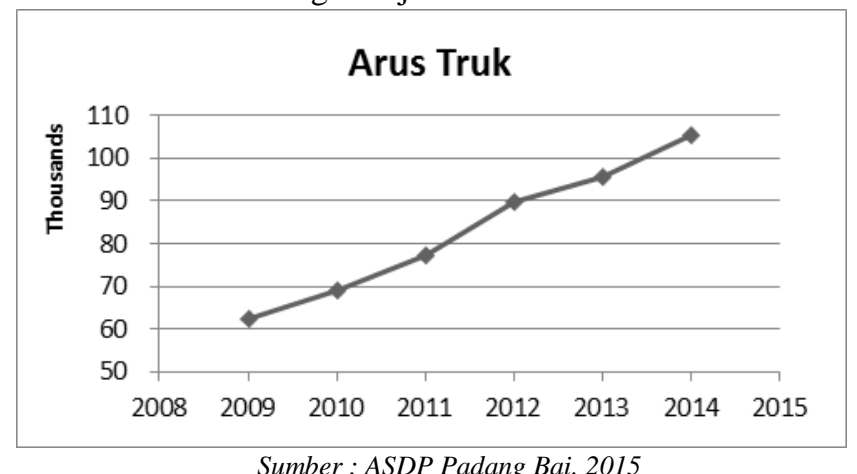

Gambar 2 Arus truk di Padang Bai

Dari Gambar 2 diketahui bahwa arus truk mengalami peningkatan dari tahun ke tahun.

b. Kendaraan Pribadi

Selain truk, muatan yang menyeberang melalui Padang Bai adalah kendaraan pribadi. Kendaraan pribadi ini dibagi menjadi dua, yaitu roda empat dan roda 2. Arus kendaraan pribadi juga mengalami peningkatan dari tahun ke tahun, baik itu roda dua maupun roda empat.
Gambar 3 dibawah ini menerangkan grafik dari arus muatan roda dua di Padang Bai, dimana dari tahun ke tahun mengalami peningkatan.

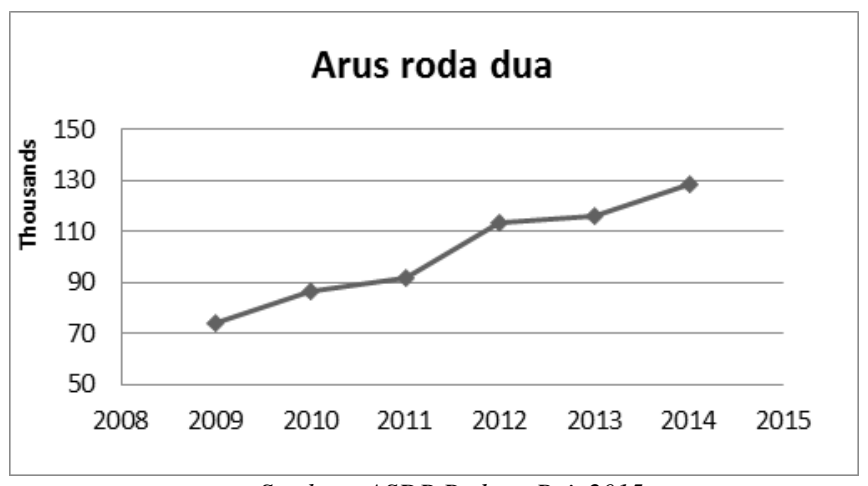

Gambar 3 Arus roda dua di Padang Bai

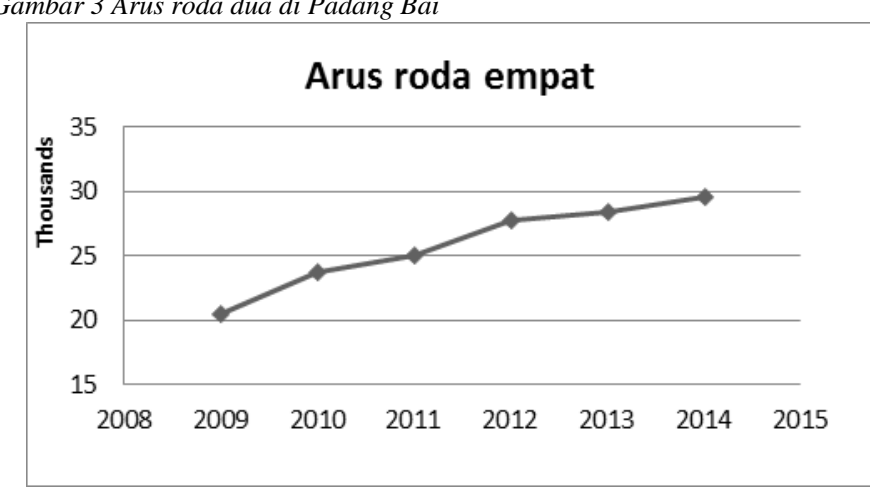

Sumber : ASDP Padang Bai, 2015

Gambar 4 Arus rode empat

Gambar 4 merupakan grafik dari arus muatan roda empat di Padang Bai.

\section{Fasilitas di Padang Bai}

Pelabuhan Padang Bai memiliki fasilitas untuk dapat melayani muatan, diantaranya :

a. Dermaga

Di pelabuhan Padang Bai terdapat 2 dermaga Movable Bridge

b. Parkir penyeberangan

Luas parkir penyeberangan di pelabuhan Padang Bai adalah sebesar $4582 \mathrm{~m}^{2}$.

\section{ANALISIS DAN PEMBAHASAN KAPASITAS PELABUHAN PADANG BAI}

\section{A. Peramalan Arus Muatan}

Dalam melakukan peramalan arus muatan metode yang digunakan adalah regresi linear sederhana, dimana untuk melakukan proyeksi terlebih dahulu mencari nilai korelasi antara variable terkait dan variable bebas yang akan digunakan untuk mengetahui seberapa besar pengaruh variable bebas terhadap variable terkait[3].

a. Proyeksi arus truk

$$
\boldsymbol{y}=\boldsymbol{a}+\boldsymbol{b} \boldsymbol{x}
$$

Dalam melakukan proyeksi arus truk, pertama masingmasing unit truk tersebut di konversikan kedalam muatan yang dibawa, muatan dari truk tersebut yang akan di proyeksikan, setelah mengetahui proyeksi arus cargo, kemudian arus cargo tersebut dikonversikan lagi kedalam masing-masing unit truk. Variable bebas yang 
digunakan untuk memproyeksikan arus cargo truk adalah PDB NTB dengan nilai determinasi $\left(\mathrm{r}^{2}\right)$ sebesar 0.63. Persamaan regresi linear sederhana pertumbuhan arus cargo dengan pertumbuhan PDB NTB adalah

$$
y=-0.4532+9.4669 x
$$

Tabel 1.

Hasil persamaan linear PDB NTB dengan Cargo truk

\begin{tabular}{ccc}
\hline \hline & \multicolumn{2}{c}{ Hasil persamaan linear } \\
\hline Asumsi & Laju PDB & Pertumbuhan Arus cargo \\
pertumbuhan & NTB $(\mathrm{x})$ & truk $(\mathrm{y})$ \\
Pesimis & $5 \%$ & $2.01 \%$ \\
Moderate & $5.3 \%$ & $4.85 \%$ \\
Optimis & $5.6 \%$ & $7.69 \%$
\end{tabular}

Tabel 1 diatas merupakan hasil dari persamaan linear Laju PDB NTB dengan Pertumbuhan Arus Cargo truk, jika laju PDB NTB pesimis yaitu sebesar 5\% maka pertumbuhan cargo tumbuh sebesar $2.01 \%$. Setelah mengetahui proyeksi dari arus cargo, kemudian arus cargo tersebut dikonversikan kedalam unit truk, dengan cara membagi dengan persentase muatan yang dibawa masing-masing golongan truk, dam kemudian dibagi dengan kapasitas masing-masing truk.

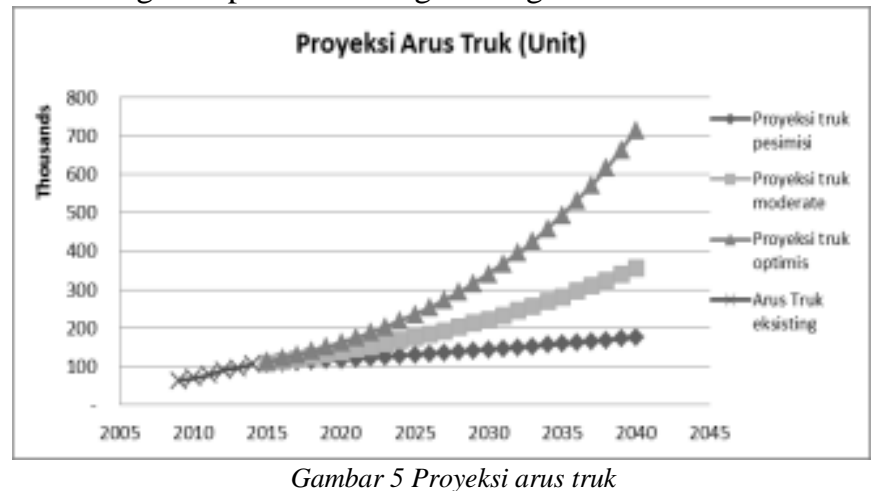

Gambar 5 merupakan grafik dari proyeksi arus truk, arus truk mengalami pertumbuhan di tahun mendatang.

b. Proyeksi kendaraan pribadi

Dalam melakukan proyeksi kendaraan pribadi, dikonversikan terlebih dahulu kedalam muatan yang dibawa oleh kendaraan tersebut. Variable bebas yang digunakan adalah tenagakerja Bali dengan nilai determinasi $\left(\mathrm{r}^{2}\right)$ sebesar 0.81. Persamaan regresi linear anatar penumpang kendaraan pribadi dengan tenagakerja Bali adalah

$$
\begin{gathered}
y=0.024+2.17 x \\
\text { Tabel } 1 .
\end{gathered}
$$

Hasil persamaan linear tenaga kerja bali dengan penumpang kendaraan

\begin{tabular}{ccc}
\hline \hline & \multicolumn{2}{c}{ Hasil persamaan regresi linear } \\
\hline Asumsi & Pertumbuhan & Pertumbuhan \\
pertumbuhan & tenagakerja Bali $(\mathrm{x})$ & penumpang kendaraan (y) \\
Pesimis & $1.0 \%$ & $4.60 \%$ \\
Moderate & $2.0 \%$ & $6.77 \%$ \\
Optimis & $3.0 \%$ & $8.94 \%$ \\
\hline \hline
\end{tabular}

Tabel 2 diatas merupakan tabel hasil persamaaln linear pertumbuhan tenaga kerja Bali dengan pertumbuhan penumpang kendaraan. Setelah mengetahui proyeksi penumpang kendaraan, kemudian dibagi dengan persentase muatan yang dibawa oleh masing-masing golongan kendaraan dan dibagi dengan kapasitas masing-masing kendaraan.

Gambar 6 dibawah ini menggambarkan dari proyeksi kendaraan pribadi di tahun-tahun kedepan. Dimana menurut hasil dari proyeksi, arus kendaraan pribadi mengalami peningkatan sebesar $4.06 \%$ jika pertumbuhan tenaga kerja bali meningkat $1 \%$, dan arus kendaraan pribadi akan meningkat sebesar $6.77 \%$ jika tenagakerja Bali meningkat sebesar $2 \%$, dan kendaraan pribadi akan meningkat sebesar $8.94 \%$ jika tenagakerja bali meningkat sebesar 3\%.

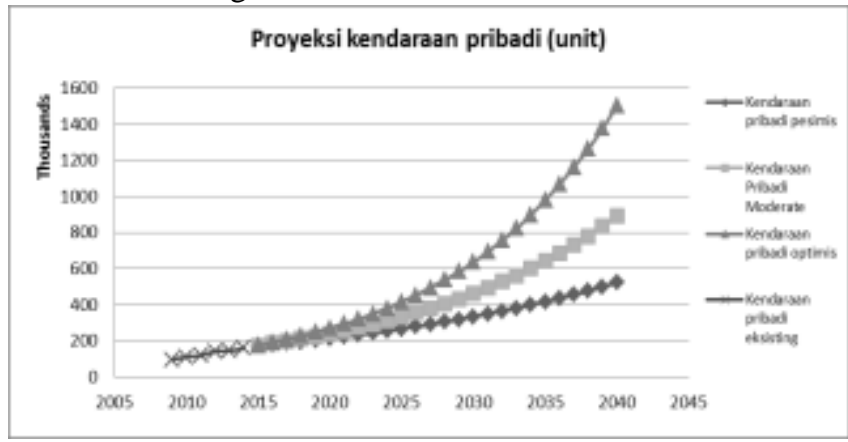

Gambar 6 Proyeksi kendaraa pribadi

\section{B. Analisis Kapasitas Pelabuhan}

Dalam tahap ini akan dilakukan analisa terhadap kapasitas di pelabuhan Padang Bai, untuk mengetahui apakah kapasitas yang tersedia sekarang masih mampu melayani arus muatan ditahun kedepannya.

a. Analisis Load factor

Karena pelabuhan Padang Bai merupakan pelabuhan penyeberangan, dimana pola operasi kapal linier atau sudah terjadwal keberangkatan kapal dari kapal, maka untuk mengetahui kapasitas dermaga digunakan analisis load factor [4]

$L f=\frac{\text { Kapasitas terpakai }}{\text { Kapasitas tersedia }} \times 100 \%$.

Dari hasil survey yang penulis lakukan di Padang Bai, diketahui bahwa :

Tabel 2.

Waktu Baku Kapal di Pelabuhan

\begin{tabular}{cccccc}
\hline \hline Kapasi & menaik & menurun & manu & manu & Wak \\
tas kapal & $\begin{array}{c}\text { kan } \\
\text { kendaraan } \\
\text { (menit) }\end{array}$ & $\begin{array}{c}\text { kendaraan } \\
\text { (Menit) }\end{array}$ & $\begin{array}{c}\text { ver kapal } \\
\text { datang } \\
\text { (Menit) }\end{array}$ & $\begin{array}{c}\text { ver kapal } \\
\text { pergi } \\
\text { (Menit) }\end{array}$ & $\begin{array}{c}\text { tu Baku } \\
\text { kapal } \\
\text { (menit) }\end{array}$ \\
\hline 26 & 52 & 13 & 15 & 7 & 87
\end{tabular}

Tabel 3 merupakan waktu kapal di pelabuhan, dimana untuk 1 kapal memerlukan waktu 87 menit di pelabuhan, untuk keamanan maka dibulatkan menjadi 120 menit, sehngga 1 kapal yang sandar rata-rata membutuhkan waktu selama 120 menit di pelabuhan, dengan jumlah dermaga sebanyak 2 buah dan hari operasional pelabuhan selam 24 jam/hari maka setiap 1 jam sekali ada kapal yang datang. Jadi kapasitas tersedia di pelabuhan Padang Bai untuk melayani muatan adalah 26 unit per jam. 


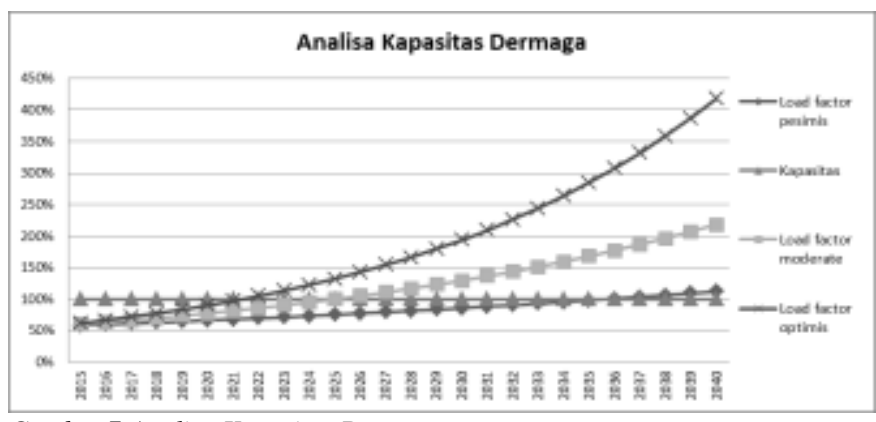

Gambar 7 Analisa Kapasitas Dermaga

Gambar 7 merupakan grafik dari analisa dermaga, dimana dengan 2 dermaga yang dimiliki pelabuhan Padang Bai saat ini tidak dapat melayani arus muatan ditahun-tahun mendatang, jika pertumbuhan arus pesimis akan terjadi antrian di Tahun 2038, jika pertumbuhan moderate akan terjadi antrian di tahun 2027, dan jika pertumbuhan arus optimis maka akan terjadi antri di tahun 2023.

b. Analisi Lapangan Parkir

Pelabuhan Padang Bai memiliki parkir penyeberangan seluas $4582 \mathrm{~m}^{2}$. Untuk mengetahui kebutuhan parkir penyeberangan digunakan persamaan sebagai berikut [3] :

$$
B 1=b \cdot n \cdot N \cdot X \cdot Y(m 2)
$$

$B 1=$ Luas parkir menyebrang

$B=$ areal parkir per kendaran

$n=$ jumlah kendaraan per kapal

$N=$ Jumlah kapal sandar/bertolak dalam waktu bersamaan

$X=$ Rasio antara jumlah kendaraan terbanyak dalam 1 haru dengan jumlah kendaraan per kapal

$Y=$ fluktuasi rasio $(1,2)$

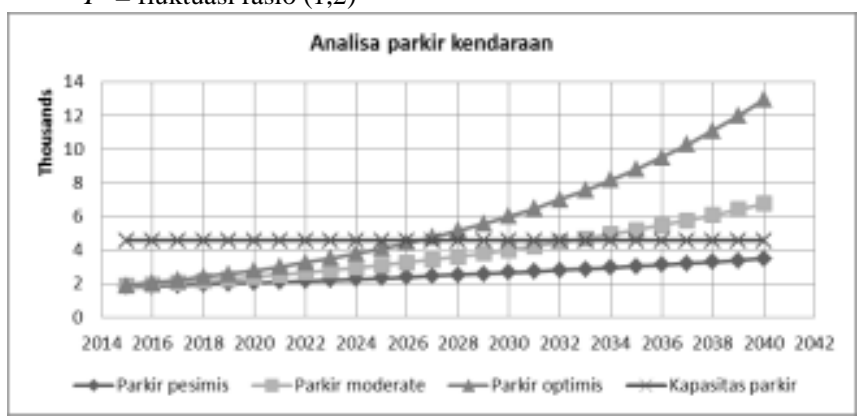

Gambar 8 Analisa Parkir kendaraan penyeberangan

Gambar 8 diatas merupakan grafik dari kebutuhan parkir penyeberangan di pelabuhan Padang Bai, dimana ketika pertumbuhan arus pesimis kapasitas parkir pelabuhan masih dapat melayani arus muatan hingga 2040, jika pertumbuhan muatan moderate maka kapasitas parkir tidak dapat melayani arus muatan di tahun 2034, dan jika petumbuhan muatan optimis maka kapasitas parkir tidak dapat melayani arus muatan di tahun 2028.

\section{Analisis Kerugian Akibat Antrian}

Karena fasilitas pelabuhan tidak dapat melayani arus muatan, maka terjadi antrian. Kerugian akibat antrian yaitu biaya operasioanl kendaraan akan bertambah, disamping itu akan ada biaya peluang yang hilang dari atau disebut opportunity cost dari muatan yang dibawa truk.

Biaya operasional = biaya tetap + biaya variable Opportunity cost $=$ Jumlah barang *harga barang*suku bunga*lama penundaan

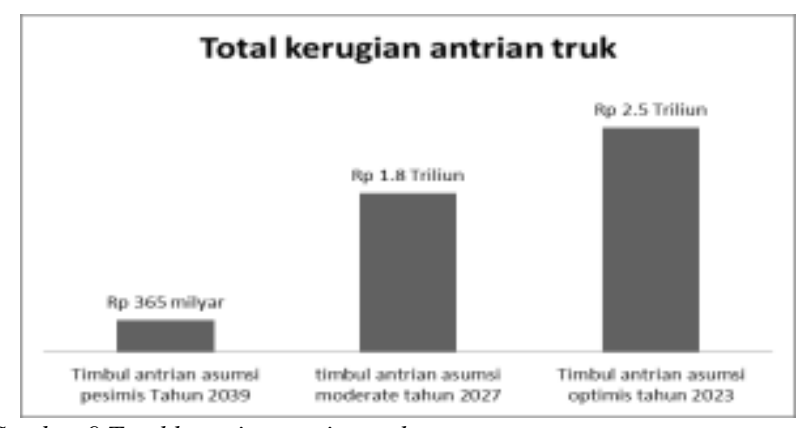

Gambar 9 Total kerugian antrian truk

Gambar 9 merupakan diagram dari kerugian truk akibat antrian. Dimana jika pertumbuhan truk pesimis akan terjadi antrian di tahun 2039 dengan total kerugian akibat antrian di tahun 2039 sebesar Rp 365 miliyar.

\section{Total opportunity cost}

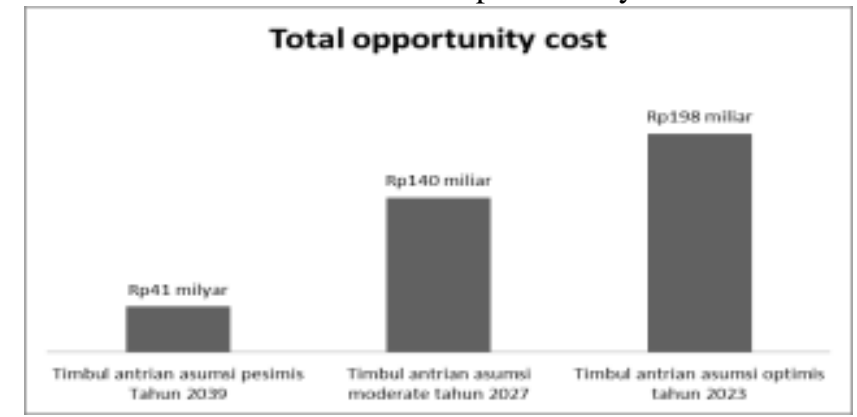

Gambar 10 Opportunity cost akibat antrian

Gambar 10 merupakan diagram opportunity cost akibat antrian, dimana ketiak pertumbuhan arus muatan pesimis terjadi antrian di tahun 2039 dengan total opportunity cost di tahun 2039 sebesar Rp 41 Miliyar.

D. Keuntungan dan Kerugian Jika Pelabuhan Barang di Padang Bai dan Jika Pelabuhan Barang di Amed

\section{PENGAMBILAN KEPUTUSAN}

\section{A. Kriteria Pengambilan Keputusan}

a. Biaya Operasional Truk

Truk yang menyeberang di pelabuhan Padang Bai kebanyakan berasal dari Jawa, jika pelabuhan penyeberangan dipindah maka biaya operasional truk tersebut akan berubah.

\begin{tabular}{ccc}
\multicolumn{3}{c}{ Tabel 3 Biaya operasional truk } \\
\hline \hline Biaya operasional truk & & \\
\hline Rute & & Biaya \\
Gilimanuk - Padang Bai & Rp & $1,428,076$ \\
Gilimanuk - Amed & Rp & $1,506,398$ \\
\hline \hline
\end{tabular}

Tabel 8 merupakan biaya operasional truk jika pelabuhan di Padang Bai dan di Amed. Karena biaya operasional truk di Padang Bai lebih murah maka nilai untuk biaya operasional truk 1 , sedangkan amed 0 .

b. Jarak Pelayaran ke Lombok.

Jarak pelayaran berpengaruh pada biaya operasional kapal dan juga waktu penyeberangan, semakin dekat jarak pelayaran maka semakin murah biaya operasional kapal.

Tabel 4.

Jarak pelayaran ke Lombok

\begin{tabular}{cc}
\multicolumn{2}{c}{ Jarak pelayaran ke Lombok } \\
\hline \hline Alternatif & Jarak (mile) \\
\hline Padang Bai & 43 \\
Amed & 30 \\
\hline \hline
\end{tabular}

Tabel 9 merupakan jarak pelayaran menuju ke Lombok dari Amed dan dari Padang Bai.

c. Kebisingan 
Akibat dari arus kendaraan maka akan menimbulkan kebisingan.

Tabel 5.

Kebisingan kendaraan

\begin{tabular}{cc}
\multicolumn{2}{c}{ Kebisingan } \\
\hline \hline Alternatif & Kebisingan \\
Padang Bai & 62.6 \\
Amed & 54.3 \\
\hline \hline
\end{tabular}

Tabel $10 \overline{\text { merupakan kebisingan dari }}$ setip alternatif, dimana ketika pelabuhan barang dipindah ke Amed maka akan menghasilkan kebisngan lebih rendah.

d. Emisi

Arus kendaraan akan mengakibatkan pencemaran bagi lingkungan dari gas buang kendaraan.

$$
\text { Tabel } 6 .
$$

Rekaptulasi Nilai emisi ISPU di Padang Bai dan Amed

\begin{tabular}{clll}
\hline \hline Lokasi & CO & SO2 & NO2 \\
\hline Padang Bai & 16.5 & 0.0212 & 0.128 \\
Amed & 3.18 & 0.0193 & 0.117 \\
\hline
\end{tabular}

Tabel 11 merupakan nilai ISPU emisi di Padang Bai dan Amed.

e. Kerugian Antrian

Kerugian yang terjadi akibat antrian diantaranya bertambahnya biaya operasional truk dan timbulnya opportunity cost dari mutan yang dibawa.

Tabel 7.

Kerugian truk akibat antrian

\begin{tabular}{cc}
\hline \hline Alternatif & Kerugian kendaraan \\
\hline Padang Bai & Rp 1.8 Triliyun \\
Amed & 0 \\
\hline \hline
\end{tabular}

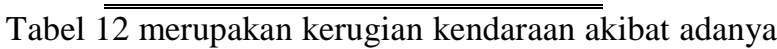
antrian, di Amed tidak ada kerugian karena pelabuhan Amed dibangun sesusai dengan proyeksi arus muatan untuk 25 tahun kedepan.

$$
\text { Tabel } 8 .
$$

\begin{tabular}{cc}
\multicolumn{2}{c}{ Opportunity cost akibat antrian } \\
\hline \hline Alternatif & Kerugian kendaraan \\
Padang Bai & Rp 140 Miliyar \\
Amed & 0 \\
\hline \hline
\end{tabular}

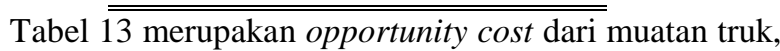
karena tidak adanya kerugian antrian maka alternatif Amed memperoleh nilai1.

f. Biaya Investasi Karena membangun pelabuhan baru, maka biaya investasi di Amed lebuh besar dari di Padang Bai.

$$
\text { Tabel } 9 .
$$

Biaya investasi pelabuhan

\begin{tabular}{cc}
\hline \hline Alternatif & Biaya investasi pelabuhan \\
\hline Padang Bai & Rp 46 Miliyar \\
Amed & Rp. 154.27 Miliyar \\
\hline \hline
\end{tabular}

Tabel 14 merupakan biaya investasi masing-masing alternatif, pelabuhan Padang Bai memperoleh nilai 1 karena biaya investasi yang dikeluarkan lebih sedikit.

g. RDTR Karangasem

RDTR merupakan rencana tata ruang suatu wilayah, pembangunan dari suatu wilayah mengacu pada RDTR wilayah tersebut.

\begin{tabular}{cc}
\multicolumn{2}{c}{ Tabel 10 RDTR Karangasem } \\
\hline \hline Alternatif & RDTR \\
\hline Padang Bai & Daerah wisata \\
Amed & Pengembangan
\end{tabular}

Tabel 15 merupakan tabel RDTR masing-masing alternatif, dimana Padang Bai masuk ke dalam Daerah
Tujuan Wisata, sedangkan Amed masuk kedalam daerah pengembangan.

\section{B. Normalisasi matriks nilai kriteria}

Dibawah ini merupakan normalisasi nilai dari masing-masing kriteria di masing-masing alternatif.

Tabel 11.

Normalisasi nilai matriks

\begin{tabular}{cccc}
\hline \hline Alternatif & \multicolumn{3}{c}{ Kriteria } \\
& Operasional truk & Jarak antar Pelabuhan \\
\hline Padang Bai & 1.00 & & 0.67 \\
Amed & 0.00 & 1.00 & \\
\hline \hline Alternatif & & Kriteria & \\
& Biaya pelabuhan & Kebisingan & Emisi CO \\
Padang Bai & 1 & 0.5 & 1 \\
Amed & 0 & 1 & 1 \\
\hline
\end{tabular}

\begin{tabular}{cccc}
\hline \hline Alternatif & Kriteria \\
& 1 & 1 & RDTR \\
\hline Padang Bai & 1 & 1 & 0 \\
Amed & 1 \\
\hline \hline
\end{tabular}

\begin{tabular}{ccc}
\hline \hline Alternatif & \multicolumn{2}{c}{ Kriteria } \\
& Kerugian antrian & opportunity cost \\
\hline
\end{tabular}

Padang Bai $\quad 0 \quad 0$

$\begin{array}{lll}\text { Amed } & 1 & 1\end{array}$

Tabel 16 merupakan normalisasi nilai matriks masing-masing kriteria.

C. Pembobotan masing-masing kriteria

Tabel 12.

Nilai bobot masing-masing kriteria

\begin{tabular}{ccc}
\hline \hline Kriteria & Bobot $(\mathrm{W})$ & Nilai W \\
\hline Biaya operasional truk & W1 & 0.04 \\
Jarak antar Pelabuhan & W2 & 0.04 \\
Biaya pelabuhan & W3 & 0.11 \\
Kebisingan & W4 & 0.07 \\
Emisi CO & W5 & 0.07 \\
Emisi NO & W6 & 0.07 \\
Emisi SO & W7 & 0.07 \\
RDTR & W8 & 0.14 \\
Biaya antrian truk & W9 & 0.14 \\
opportunity cost & W10 & 0.14
\end{tabular}

Tabel 17 merupakan nilai bobot dari masing-masing kriteria yang sudah ternormalisasi.

D. Perankingan Alternatif

$$
V i=\sum_{j=1}^{n} W j \cdot R i j
$$

di mana :

$\mathrm{Vi}=$ rangking untuk setiap alternatif

$\mathrm{wj}=$ nilai bobot dari setiap kriteria

rij = nilai rating kinerja ternormalisasi

Tabel 13.

Tabel ranking alternatif

\begin{tabular}{cccc}
\hline \hline Alternatif & Skor & Ranking & Yang terpilih \\
\hline Padang Bai & 0.52 & 2 & Tidak Sesuai \\
Amed & 0.83 & 1 & Lebih Sesuai \\
\hline
\end{tabular}


Tabel 18 merupakan ranking dari alternatif Padang Bai dan Amed, dimana nilai skor Amed lebih besar dari Padang Bai, sehingga pelabuhan barang lebih sesuai jika di Amed.

\section{PERENCANAAN PELABUHAN}

\section{A. Perencanaan Pelabuhan Amed}

Setelah diambil keputusan bahwa pelabuhan barang lebih sesuai dipindah ke Amed, maka akan dilakukan perencanaan oelabuhan di Amed.

Tabel 14.

Perencanaan pelabuhan Amed tahun 2040

\begin{tabular}{cccc}
\hline \hline \multicolumn{4}{c}{ Perencanaan pelabuhan Amed tahun 2040 } \\
\hline Perencanaan Pelabuhan Amed Tahun 2040 \\
Dermaga & Luas Parkir & Trip per hari & Armada \\
\hline \hline
\end{tabular}

B. Investasi Pelabuhan Amed

Analisis investasi digunakan untuk mengetahui kelayakan dari pembangunan pelabuhan Amed.

Dimana untuk membangun pelabuhan Amed dibutuhkan biaya sebesar Rp 154.27 Miliyar.

\section{Perencanaan Pelabuhan Padang Bai}

Dengan dipindahnya pelabuhan barang ke Amed, maka pelabuhan Padang Bai akan dikembangkan menjadi pelabuhan penyeberangan penumpang dan pariwisata.

Tabel 15.

Perencanaan pelabuhan Padang Bai tahun 2040

\begin{tabular}{|c|c|c|c|}
\hline \multicolumn{4}{|c|}{ Perencanaan Pelabuhan Amed Tahun 2040} \\
\hline Dermaga & Luas Parkir & Trip per hari & Armada \\
\hline 2 buah & $2345 \mathrm{~m}^{2}$ & 16 & 12 \\
\hline
\end{tabular}
pelabuhan Padang Bai akan membangun insfratruktur untuk dapat melayani wisatawan, seperti pusat perbelanjaan, pusat kuliner, dan transportasi publik yang memadai

\section{KESIMPULAN}

Berdasarkan penelitian dalam Tugas Akhir ini maka didaptkan beberapa kesimpulan sebagai berikut :

1. Dengan menggunakan metode regresi linear, didapatkan persamaan linear antara pertumbuhan arus cargo di Padang bai dengan laju PDB NTB.

$$
y=-0.4532+9.4669 x
$$

2. Kapasitas dermaga di pelabuhan Padang Bai hanya mampu melayani hingga tahun 2039 untuk asumsi pesimis, tahun 2027 untuk asumsi moderate, dan 2023 untuk asumsi optimis. Untuk parkir di Padang Bai asumsi pesimis mampu melayani hingga tahun 2040, asumsi moderate hingga tahun 2034, dan asumsi optimis hingga tahun 2027.

3. Kerugian akibat antrian di pelabuhan Padang Bai sebesar Rp 1.8 triliyun untuk total kerugian truk, opportunity cost muatan sebesar Rp 140 miliyar untuk asumsi moderate di tahun 2027.

4. Berdasarkan kriteria dari biaya operasional truk, biaya pelabuhan, jarak antar pelabuhan, kebisingan, emisi, RDTR Karangasem, biaya antrian truk, dan opportunity cost, dengan metode MCDM maka didapatkan keputusan bahwa pelabuhan Amed lebih sesusai digunakan sebagai pelabuhan penyeberangan truk dengan skor 0.83 dibandingkan dengam Padang Bai yang hanya memperoleh skor sebesar 0.53.

5. Perencanaan pelabuhan Amed membutuhkan 4 dermaga, dan lapang parkir penyeberangan seluas 5146 $\mathrm{m}^{2}$ untuk 25 tahun kedepan.

\section{UCAPAN TERIMA KASIH}

Penulis mengucapkan terima kasih kepada PT. ASDP Padang Bai karena telah menerima dan membantu penulis selama penelitian dan pencarian data. Ucapan terima kasih juga ditujukan kepada seluruh civitas akademik Jurusan Transportasi Laut dan Teknik Perkapalan serta semua pihak yang turut membantu penulis dalam pengarjaan Tugas Akhir ini.

\section{DAFTAR PUSTAKA}

[1] PT. ASDP Indonesia Ferry, 2015

[2] Kramadibrata, S. 2002. "Perencanaan Pelabuhan". Penerbit ITB, Edisi Kedua, Bandung.

[3] Nasution. M. N., (2004), "Manajemen Transportasi", Ghalia Indonesia, Jakarta. 